\title{
A Rare Diagnosis: Keutel Syndrome
}

\section{Nadir Bir Tanı: Keutel Sendromu}

\author{
Saniye GIRIT ๑, Ebru SENOL ๑
}

Ethics Committee Aproval: Not Applicable.

Confillict of Interest: The authors declare that they have no conflict of interest. Funding: None.

Informed Concent: Informed consent was taken.
Cite as: Girit S, Senol E. A rare diagnosis: Keutel syndrome. Medeniyet Med J. 2019;34:329-32

\begin{abstract}
Tracheobronchial cartilage calcification is a rare finding in the pediatric population. Keutel syndrome (OMIM 245150) is a very rare syndrome characterized with diffuse calcification of cartilage, brachytelephalangia, pulmonary stenosis, midline defects, stippled epiphysis in infancy, and hearing loss accompanied by recurrent respiratory infections and asthmalike attacks. Here, we present a 14-year-old patient who was followed up with the diagnosis of asthma, but did not respond to appropriate asthma treatment. She was subsequently diagnosed as having Keutel syndrome with cartilage calcification on the tracheobranchial tree and auricula, atypical facial features, recurrent otitis media, hearing loss, and recurrent asthma-like symptoms.
\end{abstract}

Keywords: Asthma; child, Keutel syndrome, pathologic calcification

öz

Çocuk popülasyonda trakeobronşial kıkırdak kalsifikasyonu nadir bir bulgudur. Keutel sendromu (OMIM 245150) astım benzeri ataklar ve tekrarlayan alt solunum yolu enfeksiyonları ile birlikte diffüz kıkırdak kalsifikasyonu, brakiotelofalanji, orta hat defektleri, işitme kaybı ile karakterize nadir görülen bir sendromdur. Biz burada astım tanısıyla takip edilen ancak astım tedavilerine yanıtsız 14 yaşında bir olgu sunuyoruz. Bu hasta trakeobronşial ağaç ve aurikulada kalsifikasyon, atipik yüz görünümü, tekrarlayan otitis media, işitme kaybı ve tekrarlayan astım benzeri ataklar ile Keutel sendromu tanısı aldı.

Anahtar kelimeler: Astım, çocuk, Keutel sendromu, patlojik kalsifikasyon
Received: 10 November 2018

Accepted: 24 January 2019

Online First: 27 September 2019

Corresponding Author: S. Girit

ORCID: 0000-0001-7556-6568

Istanbul Medeniyet University Medical Faculty Goztepe Research and Training Hospital, Division of Pediatric Pulmonology, Department of Pediatrics, Istanbul, Turkey

saniye.girit@medeniyet.edu.tr

\section{E. Senol}

ORCID: 0000-0001-9015-1846 Health Sciences University Medical Faculty Kartal Dr. Lutfi Kırdar Educational and Research Hospital, Department of Pediatrics, Istanbul, Turkey 


\section{INTRODUCTION}

Tracheobronchial cartilage calcification (TBCC), which is commonly seen in healthy adults and in routine radiologic investigations of the elderly without any clinical significance, is accepted as age-related degeneration. However it is a rare finding in the pediatric population. Keutel syndrome (OMIM 245150) was first described by Keutel et al. ${ }^{1}$ in 1972 in siblings of consanguineous parents. There are approximately 100 cases reported in the literature with the most common finding of abnormal cartilage calcification. Recurrent upper and lower respiratory tract infections, wheezing, and asthma are common respiratory problems in Keutel syndrome. Herein, we present a 14-year-old male who was misdiagnosed as having treatment-refractory asthma and subsequently diagnosed as having Keutel Syndrome after recognition of TBCC and other features.

\section{CASE}

A 14-year-old male patient was referred to our pediatric pneumology clinic with recurrent asthma attacks and laryngotracheitis with inspiratory stridor that did not respond to medical therapy. He had a history of recurrent asthma attacks since the age of 4 year, and recurrent laryngotracheitis attacks had supervened for the last two years. Two months previously he was admitted to hospital and chest computed tomography (CT) revealed calcification in the tracheal cartilage and bronchi. We also learned that his respiratory episodes became more frequent after he started his education at boarding school last year. He also had adenoidectomy four years ago in which there had been difficulty in intubation due to mild subglottic stenosis.

He was born to consanguineous parents who were second-degree cousins and he has 3 healthy siblings. He was born at term by spontaneous vaginal birth without any known complications. From the age of one he had hoarseness in his voice, and at age 4 , he started to receive inhaler therapy. His family reported that he did not benefit from betaagonists such as salbutamol. He had received immunotherapy for four years, which also did not reduce his attacks. He had a history of recurrent ear infections and hearing loss.

In his physical examination, mid-facial hypoplasia and depressed nasal bridge, and palpable nodules in bilateral auricula were detected. A respiratory examination revealed bilateral diffuse wheezing; while other systems were normal. His weight was at the $50-75^{\text {th }}$ percentile, whereas his height was at the $10-25^{\text {th }}$ percentile. Chest radiography showed a normal-sized heart with tracheal and bronchial calcifications. CT revealed diffuse calcification in all laryngeal cartilages and epiglottis, thickening in the cricoid cartilage and narrowing of the airway at that level, and calcification and segmentary stenosis in the anterior and lateral walls of the trachea (Figure 1). There was also calcification in the main and bilateral segmentary bronchi (Figure 2), in bilateral external auditory meatus, auricular cartilages, and in bilateral Eustachian tubes (Figure 3). Tuberculin skin test was negative and vascular flow was normal in Doppler ultrasonography of the main arteries. Electrocardiography, echocardiography, and ocular examinations were normal. Spirometry results were as follows: forced vital capacity (FVC): 67\%, forced expiratory volume in one second (FEV1):49\%, and FEV1/FVC ratio: 0.73 . A reversibility test with salbutamol was negative.

Biopsies were taken from the nodules in auricula,

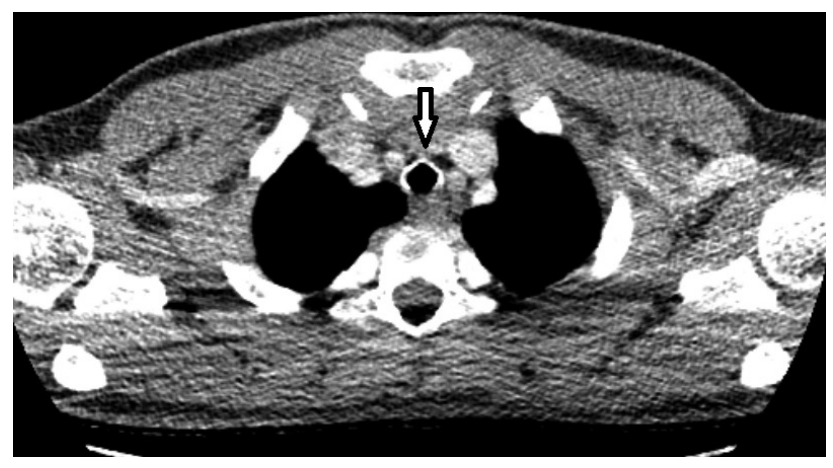

Figure 1. Calcification in tracheal cartilages, Thorax CT. 


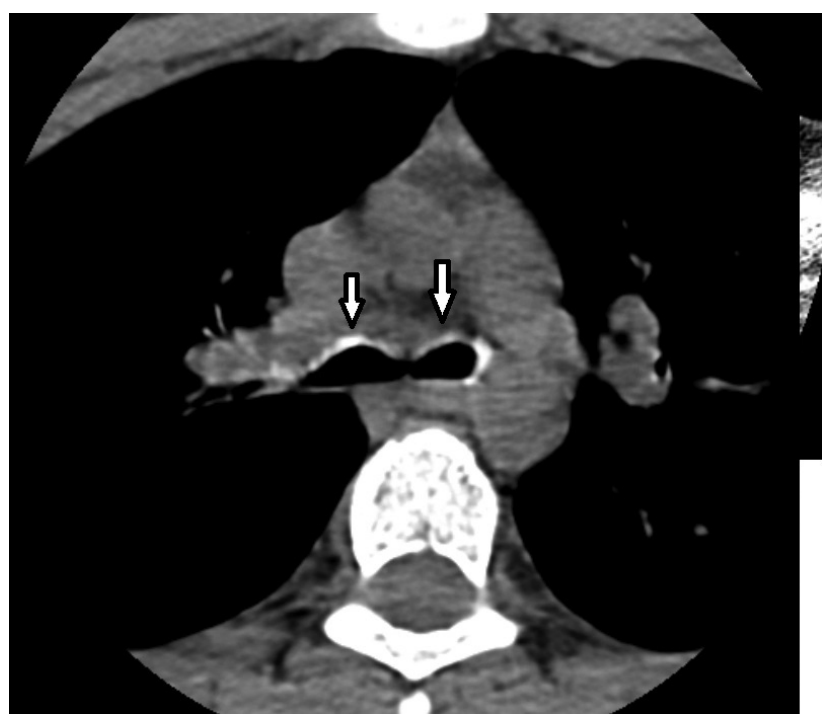

Figure 2. Calcification in right and left main bronchi starting from carina, Thorax CT.

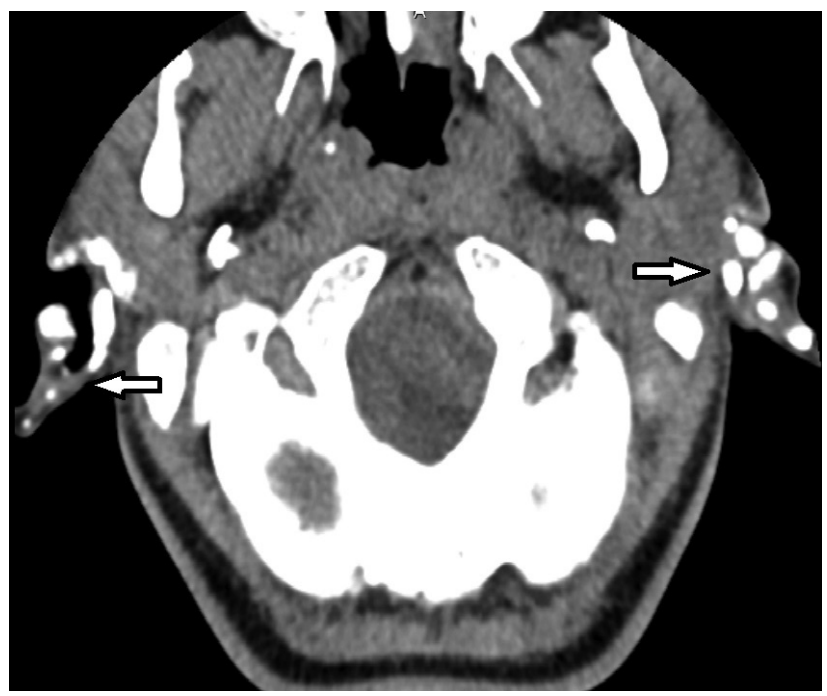

Figure 3. Calcification in auricular cartilage, Cranial CT.

which revealed ossified cartilage tissue in fibrocollagenized connective tissue. The patient was diagnosed as having Keutel syndrome with abnormal cartilage calcification on the tracheobronchial tree and auricula, atypical facial features, recurrent otitis, asthma-like symptoms, and hearing loss.

\section{DISCUSSION}

TBCC can be seen in healthy elderly subjects and is usually of no clinical significance; however, it is very rare in children. In adults there can be ac- quired TBCC in tracheobronchopathia osteochondroplastica, relapsing polychondritis, and tracheal amyloidosis. TBCC can also be congenital due to the teratogenic effect of warfarin, and also seen in Williams syndrome, chondrodysplasia punctate, and Keutel syndrome ${ }^{2}$. There are also some studies suggesting that long-term warfarin use in childhood can also result in $\mathrm{TBCC}^{3}$.

Keutel syndrome is a very rare autosomal recessive disorder with a prevalence of 1:1000000. The characteristics of the syndrome include diffuse calcification of cartilage, brachytelephalangia, pulmonary stenosis, mid-line defects, stippled epiphysis in infancy, and hearing loss ${ }^{4}$. There are approximately 100 reported cases of Keutel syndrome, in which the most common disorder is abnormal cartilage calcification. Most cases also have midline defects such as depressed nasal bridge, midface hypoplasia, pulmonary stenosis or ventricular septal defects. Frequent upper and lower respiratory tract infections and wheezing episodes are also common with no reversibility in spirometry. Our patient had atypical facial features, diffuse laryngotracheal, bronchial calcification, auricular cartilage ossification, hearing loss, short stature, recurrent upper and lower respiratory tract infections, and wheezing attacks with no reversibility.

A genetic study in Turkish and Belgian patients with consanguineous parents showed that the responsible mutation was in the gene encoding human Matrix Gla protein (MPG) through homozygosity mapping. MGP is a skeletal extracellular matrix protein, mapped to locus $12 \mathrm{p} 13.1-\mathrm{p} 12.3$, and also a member of the G1a protein family, which includes osteocalcin and factors II, VII, IX, X and proteins $\mathrm{S}$ and $\mathrm{C}^{5}$.

Keutel syndrome should be distinguished from relapsing polychondritis. Relapsing polychondritis is a disorder that can be seen at any age, but most frequently in the fifth decade, in which recurrent chondritis of the ears, nose, larynx, and tracheo- 
bronchial tree can result in tracheobronchial obstruction in advanced cases. There is also recurrent auricular inflammation in $85 \%$ of the patients with acanthotic hyperplastic stratified squamous epithelium, collagen degeneration in the dermis, and lymphocytes, neutrophils, and fibrosis in the perichondrial area in pathology. This is mostly an autoimmune disease that has good response to steroids ${ }^{6}$. Our patient had no auricular inflammation in the biopsy but had ossification; while all autoimmune markers were negative.

Our patient had abnormal cartilage calcification in the tracheobronchial tree and auricula, atypical facial features, recurrent otitis, asthma-like symptoms, and hearing loss as findings of Keutel syndrome, and when he presented he had a diagnosis of asthma. Children who are followed as having asthma but with negative reversibility in spirometry or having recurrent croup attacks should be radiologically evaluated for tracheobronchial tree calcification. Keutel syndrome is a rare disorder in children but should always be kept in mind, especially in the presence of tracheobronchial calcification, brachytelephalangia, midline defects, and cardiac disorders.

\section{REFERENCES}

1. Keutel J, Jörgensen G, Gabriel P. A new autosomal-recessive hereditary syndrome. Multiple peripheral pulmonary stenosis, brachytelephalangia, inner-ear deafness, ossification or calcification of cartilages. Dtsch Med Wochenschr. 1971;96:1676-81. [CrossRef]

2. Ozdemir N, Ersu R, Akalin F, et al. Tracheobronchial calcification associated with Keutel syndrome. Turk J Pediatr. 2006;48:357-61.

3. Golding LP, Walsh MJ, Summer TE, Nakagawa TA. Tracheobronchial calcifications in children. Pediatr Radiol. 2013;43:937-40. [CrossRef]

4. Khosroshahi HE, Sahin SC, Akyuz Y, Ede H. Long-term follow-up of four patients with Keutel Syndrome. Am J Med Genet A. 2014;164A:2849-56. [CrossRef]

5. Munroe PB, Olgunturk RO, Fryns JP, et al. Mutations in the gene encoding the human matrix Gla protein cause Keutel syndrome. Nat Genet. 1999;21:142-4. [CrossRef]

6. Cantarini L, Vitale A, Brizi MG, et al. Diagnosis and classification of relapsing polychondritis. J Autoimmun. 2014;48-49:53-9. [CrossRef] 